\title{
$\therefore$ \\ Histopathological Study of Endoscopic Upper Gastrointestinal Tract Biopsy
}

IJCRR

Section: Healthcare

ISI Impact Factor

(2019-20): 1.628

IC Value (2019): 90.81

$\operatorname{SJIF}(2020)=7.893$

(c) (7) (8)

Copyright@IJCRR

\author{
Shaikh Imran Y. ${ }^{1}$, Savalia Charmi H. ${ }^{2}$, Gandhi Minesh B ${ }^{3}$, Shah Cherry $K^{4}$ \\ Jr. Lecturer, Department of Pathology, Smt. N.H.L Municipal Medical College, Ahmedabad, Gujarat, India; ${ }^{2}$ nd-year Resident Doctor, Depart- \\ ment of Pathology, Smt. N.H.L Municipal Medical College, Ahmedabad, Gujarat, India; ${ }^{3}$ Associate Professor, 4 Professor\& HOD, Department of \\ Pathology, Smt. N.H.L Municipal Medical College, Ahmedabad, Gujarat, lndia.
}

\section{ABSTRACT}

Introduction: Upper gastrointestinal tract disorders are one of the most commonly encountered problems in clinical practice.1Endoscopic procedure is performed for a variety of benign and malignant lesions. The definitive diagnosis of upper gastrointestinal tract disorders rests on histopathological confirmation and is one of the bases for proper management and treatment.

Objective: To determine the spectrum of histopathological lesions of the upper gastrointestinal tract.

To establish endoscopic biopsy as an effective tool in the proper diagnosis of various upper gastrointestinal tract lesions.

Material \& Method: A retrospective study of 212 upper gastrointestinal endoscopic biopsies \&histopathological assessment was done at the department of pathology, Smt. NHL Municipal Medical College and Sheth VS general hospital from Sep 2018- Feb 2020.

Results: Of the total 212 cases of the oesophagus, stomach and duodenal biopsies, $66.98 \%$ were non-neoplastic lesions and 33.02 were neoplastic lesions. The most common malignancy was squamous cell carcinoma in the oesophagal biopsy. In stomach biopsy chronic gastritis (37.5\%) was the most common lesion. In duodenal biopsy chronic nonspecific duodenitis (75\%) was the most common lesion.

Conclusion: In our study, the commonest site for upper gastrointestinal tract biopsy was the duodenum (34.38\%) with $75 \%$ nonneoplastic lesions, followed by oesophagus (33.01\%) $31.4 \%$ non-neoplastic and $68.57 \%$ neoplastic lesions. The least common site for biopsy was the stomach (30.1\%).In the stomach, non-neoplastic lesions were more common.

Key Words: Endoscopy, Biopsy, Histopathology, Upper gastrointestinal tract, Non-neoplastic lesions, Neoplastic lesions

\section{INTRODUCTION}

Upper gastrointestinal tract disorders are one of the most commonly encountered problems in clinical practice with a high degree of morbidity and mortality. Endoscopic biopsy is the common procedure performed in hospitals for varieties of benign \& malignant lesions.

Oesophagus and stomach can be sited for a wide variety of infections, inflammatory disorders, vascular diseases, mechanical conditions, toxic and physical reactions including radiation injury and neoplasm.

Histopathological study of the biopsy specimen is used to confirm the endoscopic diagnosis in suspected malignancies /to rule out malignancy in the endoscopically appearing benign lesion.

Endoscopic biopsies are also used for monitoring the course, to determine the extent of the disease, response to therapy and early detection of complications. ${ }^{2}$

\section{AIMS AND OBJECTIVES}

To determine the spectrum of histopathological lesions of the upper gastrointestinal tract.

To establish endoscopic biopsy as an effective tool in the proper diagnosis of various upper gastrointestinal tract lesions.

\section{Corresponding Author:}

Dr. Savalia Charmi H., 2nd-year Resident Doctor, Department of Pathology, Smt. N.H.L Municipal Medical College, Ahmedabad, Gujarat, India; Email: Charmisavalia897@gmail.com

ISSN: 2231-2196 (Print)

Received: 12.02 .2021
ISSN: 0975-5241 (Online)

Revised: 04.03 .2021
Accepted: 26.06 .2021
Published: 01.12 .2021 


\section{MATERIAL \& METHODS}

The present study included 212 endoscopic biopsies of the upper gastrointestinal tract. They were taken from patients who were clinically diagnosed to have upper gastrointestinal tract lesions at the department of gastro medicine at Smt. NHL MMC and Sheth VS general hospital from Sep 2018Feb 2020.

The endoscopic equipment used for endoscopy \& biopsy was OLYMPUS CF-H170L/I. Key benefits of this instrument are HDTV image quality, narrow-band imaging (NBI), close focus, variable stiffness, water jet and waterproof connector.

The biopsy specimen was put in saline and placed in filter paper with mucosal surface upwards. The filter paper was immersed in $10 \%$ formalin for fixation then the tissue was routinely processed and embedded in paraffin. 5 micron thick sections were cut perpendicular to the mucosal surface. 4-5 sections were prepared on each slide. Each section was stained with H\&E and studied microscopically and the attempt was made to diagnose the lesion on gross visualization during endoscopy and to correlate them histopathologically. Special stain Giemsa stain was used to look for H. Pylori infection. Alcian blue(at ph 2.5) \& PAS stain was used to detect acid mucin in true goblet cells in Barrett's oesophagus.

\section{RESULTS}

As cited in table 1 out of a total of 212 GI endoscopic biopsies, $125(58.96 \%)$ were from males and 87 (41.03\%) were from females with M: F ratio being 1.4:1. Age of patients ranged between 16-72 years with the majority of patients being in the age group between $40-60$ years $(57.5 \%)$ and 2 nd most common age group is $20-40(32.08 \%)$ years followed by $>60$ years $(8.9 \%)$ and $<20$ years $(1.41 \%)$.

The site-wise distribution of endoscopic biopsies were duodenum $76(35.85 \%)$, esophagus $70(33.02 \%)$ and stomach $66(31.13 \%)$ cases(Table 2). The most common site was the duodenum followed by the oesophagus and stomach.

As cited in table 3 out of 70 cases of oesophagal biopsies, there were 48 neoplastic lesions and 22 non-neoplastic lesions. Squamous cell carcinoma was the most common neoplastic lesion with 40 cases. The majority of oesophagal squamous cell carcinoma were moderately differentiated with $31(77.5 \%)$ cases followed by poorly differentiated with 4 cases, basaloid pattern with 3 cases and 1 case of welldifferentiated and spindle cell sarcomatoid carcinoma of each. Chronic active esophagitis was the most common nonneoplastic lesion. There were 3 cases of Barrett's oesophagus $\& 2$ cases of eosinophilic esophagitis.

In gastric biopsies, non-neoplastic lesions were more than neoplastic lesions. The most common non-neoplastic lesion was chronic gastritis with $25(52.08 \%)$ cases. There were 13 cases of gastric ulcer, 5 cases of chronic superficial gastritis, 3 cases of polyp and 1 case each of H.Pylori gastritis and tuberculous inflammation. Adenocarcinoma was the most common malignant lesion with 18 cases. Concerning differentiation, cases of moderately differentiated carcinoma were more common followed by signet ring adenocarcinoma and poorly differentiated adenocarcinoma.

The most common site for biopsy was duodenum 76 cases (35.85\%). The majority of cases were non- neoplastic 74 (97\%). Among non-neoplastic lesions, chronic nonspecific Duodenitis was the most common with 57 cases $(77.03 \%)$, followed by 3 cases of celiac sprue and Lymphangiectasiaeach, 2 cases of Crohn's disease and 1 case of Strongyloides stercoralis.

\section{DISCUSSION}

Upper gastrointestinal tract endoscopy is the investigation of choice in patients with Upper Gastrointestinal tract disorders. The present study was conducted on 212 cases of Upper Gastrointestinal tract endoscopies.

In the present study majority of the upper gastrointestinal tract, biopsies were from the duodenum $(35.85 \%)$ followed by the oesophagus $(33.02 \%)$ and stomach $(31.13 \%)$. The majority of patients were in the age group of $4^{\text {th }}$ to $6^{\text {th }}$ decade of life. These findings are comparable to findings of studies by Krishnappa $\mathrm{R}$ et $\mathrm{al}^{3}{ }^{3}$ and Katiyar V et al. ${ }^{19}$

In present study majority of the patients were males with an $\mathrm{M}$ : $\mathrm{F}$ ratio of 1:4 to 1 . These results are almost comparable to study by Hussain et al. ${ }^{8}$, Abilash SC et al. ${ }^{13}$, Shanmugaswamy et al. ${ }^{14}$, Sheikh BA et al. ${ }^{15}$ and Guliaet al. ${ }^{16}$, Katiyar V et al. ${ }^{19}$, Krishnappa R et al. ${ }^{3}$, sheikh BA et al..$^{24}$, Panjeta $\mathrm{S}$ et al..$^{22} \&$ Shennak MM et al. ${ }^{18}$

Duodenal lesions: In our study majority of cases were from the duodenum(76)with duodenal biopsies involving the first two parts of the duodenum revealing non-neoplastic lesions(74) $97.36 \%$ more than neoplastic lesions(2)2.63\%. This observation is comparable to studies conducted by Sheikh BA et al. ${ }^{15}$ \&Krishnappa $\mathrm{R}$ et al. ${ }^{3}$ Among non-neoplastic lesions chronic nonspecific duodenitis was the leading diagnosis which is comparable with the study by Khadinge et al. ${ }^{17}$ This may be because the duodenum has rapidly regenerated epithelial lining which can be easily affected by any inflammatory insult. Among malignant lesions, both were found to be adenocarcinoma which is comparable with findings of the study conducted by Sheikh BAet al. ${ }^{15}$ which also shows adenocarcinoma is the most common malignancy of duodenum.

Oesophagal lesions: In the present study out of 70 cases with oesophagal lesions, $68.57 \%$ were neoplastic lesions and $31.42 \%$ were non-neoplastic lesions. These findings are 
comparable to study conducted by Bukhari $\mathrm{U}$ et al. ${ }^{20}$ In neoplastic lesions the most common carcinoma was squamous cell carcinoma with 40 cases $(83.33 \%)$ which is comparable with the study by Abilash SC et al. ${ }^{13}$, Shanmugasamy et al. ${ }^{14}$, Bukhari U et al..$^{20}$, Krishnappa R et al. ${ }^{3}$, and khan $\mathrm{N}$ A et al. ${ }^{21}$ followed by adenocarcinoma with 1 case. Most patients with oesophagal carcinoma were found between $4^{\text {th }}-6^{\text {th }}$ decades of life which is comparable to study by Krishnappa $\mathrm{R}$ et al. ${ }^{3}$, Panjeta $\mathrm{S}$ et al. ${ }^{22}$, Khan $\mathrm{N}$ A et al. ${ }^{21}$, Khandige et al. ${ }^{17}$ and Guliaet al. ${ }^{16}$ The overall late age of presentation of oesophagal cancer can be due to absence of serosa and distensibility of the oesophagus which delays the symptoms of oesophagal cancer until the tumour is advanced. Oesophagal malignancy shows a male preponderance with $\mathrm{M}$ : F ratio being 2:1 which is comparable to a study by Krishnappa $\mathrm{R}$ et al. ${ }^{18}$ In our study majority of neoplastic lesions were seen arising from the middle oesophagus $77.5 \%$ which suggest the middle oesophagus was the commonest site followed by the lower oesophagus $22.5 \%$, these results were comparable to study by Krishnappa R et al. ${ }^{3}$, Katiyar et al. ${ }^{19}$ and Abhilashet al. ${ }^{13}$ Squamous cell carcinoma of the oesophagus endoscopically presented as ulcer proliferative growth in $(37.5 \%) 15$ cases, ulcerated in(25\%) 10 cases, ulcer infiltrative in $(17.5 \%) 7$ cases, stenosing in $(12.5 \%) 5$ cases and proliferative in $(7.5 \%) 3$ cases. Among-neoplastic lesions eosinophilic esophagitis endoscopically presented as the feminization of the oesophagus. On microscopic appearance, there were 16 eosinophils/HPF.

Stomach lesions: Among 66 cases of gastric biopsies $72.7 \%$ (48)cases were non-neoplastic and 27. 2\%(18) cases were neoplastic. The higher number of non-neoplastic lesions these findings are comparable to studies by Thapa $\mathrm{R}$ et $\mathrm{al} .{ }^{23}$, Sheikh BA et al. ${ }^{15}$ and Krishnappa $\mathrm{R}$ et al. ${ }^{3}$ The most common non-neoplastic lesion was chronic non-specific gastritis with $(52.08 \%) 25$ cases followed by a gastric ulcer with 13 cases. Adenocarcinoma was the most common neoplastic lesion in our study with the major sub-site being the pyloric antrum of the stomach followed by the body of the stomach. These findings were comparable to study by Sheikh B A et al. ${ }^{15}$ and Thapa $\mathrm{R}$ et al. ${ }^{23}$ Majority of people having gastric malignancy were in the age group of 41-60 years which was similar to study by Khandige et al. ${ }^{17}$ Majority of neoplastic lesions were found in male with $\mathrm{M}$ : F ratio being 1.3:1 which was comparable to study conducted by Thappa $\mathrm{R}$ et $\mathrm{al} .^{23}$ and Krishnappa $\mathrm{R}$ et al. ${ }^{3}$ Adenocarcinoma of stomach endoscopically presented as ulcerative growth $50 \%$, ulceroproliferative growth $27.77 \%$, proliferative growth $16.66 \%$ and ulcer infiltrative growth $5.55 \%$ comparable to study by Krishnappa R et al. ${ }^{3}$

\section{CONCLUSION}

In our study duodenum was the most common site of upper gastrointestinal biopsy followed by the oesophagus and stomach. Histologically diagnosed chronic nonspecific duodenitis was the most common lesion from the duodenum.

Squamous cell carcinoma was the most common malignancy histologically diagnosed from the oesophagus. Dysphagia was the common clinical presentation of Squamous cell carcinoma.

In the stomach chronic non-specific gastritis was the most common diagnosed non-neoplastic lesion.

Thus, Endoscopic biopsy permits diagnosis of a specific entity \& act as a planning tool for surgical and medical therapy.

Upper gastrointestinal tract endoscopy is the effective and appropriate initial investigation to assess patients with Upper gastrointestinal tract symptoms. Histopathology is the gold standard for the diagnosis of endoscopically detected lesions.

\section{ACKNOWLEDGEMENT}

The authors acknowledge the immense help received from the scholars whose articles are cited and included in references of this manuscript. The authors are also grateful to authors/editors/publishers of all those articles, journals and books from where the literature for this article has been reviewed and discussed.

\section{Source of funding}

There is no source of funding.

\section{Conflict of interest}

There are no conflicts of interest.

\section{Author's contribution:}

Dr. Shaikh Imran Y: Concepts, design, the definition of intellectual content, literature research, data analysis, statistical analysis,

Dr. Savalia Charmi H: data acquisition, manuscript preparation, manuscript editing

Dr. Gandhi Minesh B: manuscript review

Dr. Shah Cherry K: manuscript review

\section{REFERENCES}

1. Shah JM, Atit NB, Shah FR, kakadiya SR. interpretation of upper gastrointestinal tract endoscopic biopsies - A retrospective study Int J. Sci Res. 2015;4:9.

2. Mustapha SK, Bolori MT, Ajayi NA, Nggada HA, Pindiga UH. Endoscopic findings and the frequency of H.pyloriamong dyspeptic patients in northeastern Nigeria. HMRJ. 2007;5:7881.

3. Krishnappa R, Horakerappa MS, Karar A, Mangala G. A study on histopathological spectrum of upper gastrointestinal tract en- 
doscopic biopsies. Int J Med Res Health Sci. 2013;2:418-24.

4. Bhat N. histopathological spectrum of upper gastrointestinal tract endoscopic biopsies-1-year prospective study. $\mathrm{Br} \mathrm{Bi}-$ omed Bull;6(2):315.

5. Sonu HU, Borchard F. Cancer of the distal oesophagus and cardia: incidence, tumours infiltration and metastatic spread. Ann Surg. 1986;203(2):188-95.

6. Wang J, Noffsinger A, Stemmermann G, Fenoligo-Preiser C. Esophagus squamous cell carcinoma arising in patients from the high-risk areas of north china lack an association with. Epstein Barr virus. Cancer Epidemiol Biomarkers Prev. 1999;8(12):11114.

7. Afroz Ahmed M, Bharathi. Histopathological study of neoplastic lesions of the upper gastrointestinal tract by endoscopic biopsy [thesis] submitted to Rajiv Gandhi University of Health Sciences, Karnataka April-2012.

8. Hussain SI, ReshiR, Akhter G, Beigh A. Clinico histopathological study of upper gastrointestinal tract endoscopic biopsies. IJCRR. 2015;7(16):78-85.

9. Devi Leena KR and Suvarna N. Pattern of gastrointestinal tumours in north Kerala. Indian J Cancer. 1980;17(159):163.

10. Durrani AA, YaqoobN,Abbasi S, SiddiqM, MoinS. The pattern of upper gastrointestinal malignancies in northern Punjab. Pak J Med Sci. 2009;25(2):302-7.

11. Sujata M, PatilP.V. Upper gastrointestinal endoscopic biopsies A histopathological study. A one-year cross-sectional study [thesis] submitted to KLE'S Dr. PrabhkarKoreHospital, Belgium, KLE University. Karnataka: Belgaum; 2011

12. Memon F, Balovch K, Memon AA. Upper gastrointestinal endoscopic biopsy; Morphological spectrum of lesions. Prof Med J. 2015;22(12):1574-9.

13. Abilash S, Kolalladan HG, Shreelakshmidevi S, Balamurunganvelu S. Histopathological spectrum of upper gastrointestinal tract mucosal biopsies: A retrospective study. Sch J ApplMed Sci. 2016;4(5E):1807-13.
14. Shanmugasamy K, Bhavani K, K. AV, NarshimN R, Kotasthane DS. Clinical correlation of Histopathological spectrum of upper gastrointestinal tract endoscopic biopsies with Histopathological findings and to study Histopathological profile of neoplastic and non-neoplastic lesions (April); 2016.

15. Sheikh BA, Hamdani SM, Malik R. Spectrum of neoplastic lesions of upper gastrointestinal tract- a study of endoscopic. Glob J Med Public Heal. 2015;4(4):1-8.

16. Gulia CSP, Noorunnisa MN, Balkrishna CD, Balagurunathan K. Interpretation of upper gastrointestinal Tract Mucosal Biopsies -A Study Conducted in Teaching Hospital in Puducherry, India. Int J Heal Sci J. 2012;1(3):17-24.

17. Change S, Shetty S, Thapa R. The conceding of upper gastrointestinal lesion endoscopic biopsy: a bare minimum for diagnosis. Int J Sci Res.2015;4(2): 264-6.

18. Shennak MM, Al sheik TM. Upper gastrointestinal diseases in symptomatic Jordanians: A prospective endoscopic study. Ann Saudi Med 1997;17(4):471-4.

19. Katiyar V, Gupta E, Bhuyan RK. The pattern of upper GI disorders based on endoscopy in a tertiary care hospital of Assam: A record-based study. Int J Sci Res. 2014;3(6):35-6.

20. Bukhari U, Siyal R, Memon FA, Memon JH. Oesophagal carcinoma: a review of endoscopic. biopsies. Pak J Med Sci. 2009;25:845-8.

21. Khan NA, Maqbool LM, Afroz F, Kharadi MY. Clinicopathological profile of carcinoma esopahgus and esophagogastric junction in Kashmir. JK Pract. 2004;11(3):182-5.

22. Panjeta SG, Chaudhary M, Noorunnisa N, Balakrishna CD. Interpretation of upper gastrointestinal tract endoscopic mucosal biopsies - A study 77 conducted; SN1 in teaching hospital in $\mathrm{Pu}$ ducherry, India. Int j Med Health Sci. 2012;1(3):17-24.

23. Thapa R, Lakhey M, Yadav PK, Kandel P, Aryal C. Histopathological study of endoscopic biopsies. J Nepal Med Assoc. 2013;52(190):354-6.

\section{Table 1: Age and gender wise distribution}

\begin{tabular}{lccc} 
Age & Male & Female & Total no of cases \\
0-20 & 02 & 01 & 03 \\
$>20-40$ & 48 & 20 & 68 \\
$>40-60$ & 65 & 57 & 122 \\
$>60$ & 10 & 89 & 19 \\
& 125 & 87 & 212 \\
\hline
\end{tabular}

Out of total of 212 GI endoscopic biopsies, 125(58.96\%) were in males and 87 (41.03\%) were in females with M: F ratio being 1.4:1. Age of patients ranged between 16-72 years with the majority of patients being in the age group between $40-60$ years $(57 \cdot 5 \%)$ and 2 nd most common age group is $20-40(32.08 \%)$ years followed by $>6$ oyears $(8.9 \%)$ and $<20$ years $(1.41 \%)$.

\section{Table 2: Site of Biopsy}

\begin{tabular}{lc} 
Site of Biopsy & No. of Cases \\
Esophagus & 70 \\
Stomach & 66 \\
Duodenum & 76 \\
Total & 212 \\
\hline
\end{tabular}

The site-wise distribution of endoscopic biopsies were duodenum 76 (35.85\%), oesophagus 70 (33.02\%) and stomach $66(31.13 \%)$ cases. The most common site was the duodenum followed by the esophagus and stomach. 
Table 3: Esophageal lesion

Type of Lesion

No of Cases

Chronic active Esophagitis

Eosinophilic Esophagitis

02

Barret's esophagus

03

Well differentiated SCC

o1

Moderately differentiated SCC

31

Poorly differentiated SCC

Basaloid SCC

$\begin{array}{ll}\text { Spindle cell sarcomatoid SCC } & 01\end{array}$

$\begin{array}{ll}\text { Poorly differentiated adenocarcinoma } & 01\end{array}$

$\begin{array}{ll}\text { Mild dysplasia } & 04\end{array}$

$\begin{array}{ll}\text { High-grade dysplasia } & 03\end{array}$

$\begin{array}{lr}\text { Negative for dysplasia } & 01\end{array}$

$\begin{array}{lr}\text { Total } & 70\end{array}$

Out of 70 cases of oesophagal biopsies, there were 48 neoplastic lesions and 22 non-neoplastic lesions. Squamous cell carcinoma was the most common neoplastic lesion with 40 cases. The majority of oesophagal squamous cell carcinoma were moderately differentiated with $31(77.5 \%)$ cases followed by poorly differentiated with 4 cases, basaloid pattern with 3 cases and 1 case of well-differentiated and spindle cell sarcomatoid carcinoma of each. Chronic active esophagitis was the most common non-neoplastic lesion. There were 3 cases of barret's oesophagus \& 2 cases of eosinophilic esophagitis.

Table 4: Stomach lesion

$\begin{array}{lc}\text { Type of lesion } & \text { No of cases } \\ \text { Chronic gastritis } & 25 \\ \text { Chronic superficial gastritis } & 05 \\ \text { H.pylori gastritis } & 01 \\ \text { Gastric ulcer } & 13 \\ \text { Polyp } & 03 \\ \text { Moderately differentiated adenocarcinoma } & 08 \\ \text { Poorly differentiated adenocarcinoma } & 03 \\ \text { Signet ring adenocarcinoma } & 07 \\ \text { Tuberculous inflammation } & 01 \\ \text { Total } & 66\end{array}$

In gastric biopsies, non-neoplastic lesions were more than neoplastic lesions. The most common non-neoplastic lesion was chronic gastritis with $25(52.08 \%)$ cases. There were 13 cases of gastric ulcer, 5 cases of chronic superficial gastritis, 3 cases of polyp and 1 case each of $\mathrm{H}$. Pylori gastritis and tuberculous inflammation. Adenocarcinoma was the most common malignant lesion with 18 cases. Concerning differentiation, cases of moderately differentiated carcinoma were more common followed by signet ring adenocarcinoma and poorly differentiated adenocarcinoma.

\section{Table 5: Duodenal lesion}

Chronic non specific duodenitis

Crohn's disease 
Table 5: (Continued)

Type of lesion

Celiac sprue negative

Moderately differentiated adenocarcinoma

Strongyloidesstercoralis

Total

With 76 cases duodenum is the most common site for biopsy. The majority of cases were non-neoplastic (74). Among nonneoplastic lesions chronic non-specific Duodenitis was the most common with 57(77.03\%) cases followed by 3 cases of celiac sprue and Lymphangiectasia each, 2 cases of Crohn's disease and 1 case of strongyloides stercoralis.

Table 6: Comparison of size distribution of endoscopic biopsies with other studies.

Study

Oesophagus

Stomach

$25.5 \%$

Sheikh B A et al. $(n=196)$

Krishnappa R et al. ( $n=100)$

$25 \%$

Panjeta et al. $(\mathrm{n}=192)$

Shennak et al. $(n=1605)$

Present study $(\mathrm{n}=\mathbf{2 1 2})$
$22 \%$

$33.02 \%$
No of Cases

o8

01

01

76 